\title{
Analysis on the Characteristics of the Current Female Presidents of Key Universities in China
}

\author{
Yunlan Wang ${ }^{1}$ and Yaoyao Yan $^{2, *}$ \\ ${ }^{1}$ School of Education, Jiangxi Normal University, Nanchang, Jiangxi 330022, China \\ ${ }^{2}$ The Institute of Education, Jiangxi Normal University, Nanchang, Jiangxi 330022, China \\ *Corresponding author. Email: 2738748081@qq.com
}

\begin{abstract}
In order to understand the employment situation of female presidents in China's key universities, this paper collected the employment data of 139 universities through various resources such as internet, and sorted out 8 samples of female presidents. Then by coding and analyzing the personal information of their resumes, it is pointed out that this group has many common characteristics in demography, academic background, social part-time job, post duties, etc. The results indicate that the female principals of key universities in China are mainly Communist Party members in their fifties, specialists with doctoral degrees in the science field, and who gain promotion within universities and have various academic part-time jobs.
\end{abstract}

Keywords: China; key universities; female presidents; characteristics

\section{INTRODUCTION}

With the increasing number of women receiving higher education, women's participation in higher education is also reflected in the field of educational management. As the top manager of university administration, the identity of female university presidents is of great significance to the development of universities. The development and expansion of female university presidents has promoted the development of gender equality and female leadership. According to the 2011 Academic Ranking List of American Universities published by Shanghai JiaoTong University, 7 of the top 20 presidents of world-class universities are women, including Harvard University, Massachusetts Institute of Technology and Princeton University [1].

Although the number of female head teachers has been increasing in recent years, the overall proportion remains low. The female leaders are described as "the velvet hammer" in the context of masculinity [2]. However, with the development of female principal groups, some scholars earlier pointed out that, compared with the metaphors, such as "glass cliff" and the "glass ceiling", female principals today are no longer faced with impenetrable obstacles, but more like the labyrinth described by Eagly and Carli[3]. They believe that "there are countless obstacles in the maze, some of which are hidden, while others can be seen through at a glance" [4]

The research on female principals in foreign countries started earlier and became more mature. Mary (2006) studied the success qualities of female presidents of fouryear universities or colleges in the United States [5]. Jack (2009) studied the role and responsibility of female principals [6]. However, the analysis of female university presidents in China mainly focuses on foreign first-class universities. Li Sumin, Luo Weiwei and Niu Menggang (2016) studied the characteristics of group leadership quality from the perspective of female university presidents in Europe and the United States [7]. Niu Menggang (2018), taking female presidents of American research universities as examples, elaborated the social structure map of female presidents from five aspects [8]. In fact, there are few studies on female university presidents in China, among which Wang Yinhan and Yu Kai (2015) conducted an investigation and research on female leaders in Chinese institutions by using the research method of Curriculum Vitae, and answered the common characteristics of these female leaders from ten dimensions[9]. These studies provide an analytical framework for us to study female principals, but there is no specific analysis on the leadership of female principals.

\section{DATA SOURCE AND SAMPLE}

In September, 2017, the Notice on Publishing the List of "double first class" Construction jointly issued by the Ministry of Education, the Ministry of Finance and the National Development and Reform Commission, making it clear that there are 137 "double first class" construction universities in China, including 42 world-class universities and 95 world-class discipline construction universities. It should be pointed out that the "double first class" universities include 39 former "985" universities and 73 "211" universities. In addition, three universities (China University of Geosciences, China University of Petroleum and China University of Mining and Technology) all have two campuses and appoint different leading bodies, so the two campuses of these three universities are counted according to different universities. These key universities represent universities of different types, levels and regions. Studying the female presidents of these universities will 
help us better understand the common characteristics of female presidents and provide ideas for the construction of female leaders.

The data collected are mainly from online resources, including various official websites of colleges and universities, provincial people's governments, the Ministry of Education, the news of the Communist Party of China, China's economy, etc., which are repeatedly checked and verified by search engines such as Google and Baidu. By the end of April 2021, the data collection of this research has been collected from all the presidents' resumes of 38 "985" universities (except National University of Defense Technology), 76 "211" universities, and 25 first-class discipline construction universities. Finally, the employment data of 8 female presidents have been sorted out.

\section{DATA ANALYSIS AND RESULTS}

Today, there are only 8 female principals in 139 key universities. Among the 38 "985" universities, there are only two female principals, occupying 5.1\%; There are only 4 female principals in 76 " $211 "$ universities, accounting for $5.3 \%$, and 2 female principals in 25 firstclass discipline construction universities, accounting for $8 \%$ (see Table 1).

Table 1. The distribution of female presidents in different schools

\begin{tabular}{|c|c|c|c|}
\hline Types of university & Total & Number of female presidents & Percent (\%) \\
\hline “985” & 39 & 2 & 5.10 \\
\hline "211" & 76 & 4 & 5.30 \\
\hline world-class discipline construction & 25 & 2 & 8 \\
\hline
\end{tabular}

administrative work of the school. The political outlook of CPC members is one of the important characteristics of

\subsection{Demographic Characteristics}

At present, some demographic indicators (such as gender, ethnicity, age, political outlook, etc.) are used by academia to describe the natural characteristics of principals. Due to the particularity of China's national system, colleges and universities implement the "principal responsibility system under the leadership of the Party Committee", that is, the Party Committee of colleges and universities uniformly leads the school work, and the principal is the legal representative of the school and is fully responsible for the university presidents in China. Six of the eight female principals are CPC members, accounting for $75 \%$, and the other two are members of the Revolutionary Committee, accounting for $25 \%$. Secondly, as far as ethnic groups are concerned, the eight female principals are all Han ethnic group. Finally, in terms of age, the initial age of the five female principals is no less than 55 years old, accounting for $67.5 \%$; Three of them were younger than 55 years old, accounting for $32.5 \%$. The average working age is about 55 years old. (see Table 2 )

Table 2. Demographic characteristics of female presidents

\begin{tabular}{|c|c|c|}
\hline Indicators & Details & Percent (\%) \\
\hline \multirow{2}{*}{ Age } & No less than 55 & 67.5 \\
\cline { 2 - 3 } & Less than 55 & 32.5 \\
\hline \multirow{2}{*}{ Political Outlook } & Communist party members & 75 \\
\cline { 2 - 3 } & others & 25 \\
\hline \multirow{2}{*}{ Ethnic Group } & Han & 100 \\
\cline { 2 - 3 } & Minority & 0 \\
\hline
\end{tabular}

refers to the category scholars study in nature, which is a certain scientific field or a branch of science.

\subsection{Characteristics of Educational and Academic Background}

Education background, generally refers to personal education experience; degree, namely a person obtains knowledge through study and the mark of corresponding study ability level, by the institution of higher learning that the country authorizes issue. Academic qualifications and degrees can largely reflect a person's level of education and academic attainment. The survey on the academic qualifications of eight female principals shows that all principals have doctoral degrees. It can be seen that having a doctorate is an important condition for becoming the president of a university in China. Subject background
Female principals are mainly distributed in three disciplines: engineering, pedagogy and economics, with the highest proportion of engineering, accounting for $37.5 \%$. At the same time, they have made achievements in their respective disciplines and are experts in a certain field (see Table 3). For example, Tian Hongqi, president of Central South University, has made important achievements in high-speed rail aerodynamics and driving safety technology in windy environment. As some scholars have pointed out, the phenomenon of "expert governance" in Chinese universities is, to a great extent, "scientist governance" or "engineer governance" [10]. With the internationalization of higher education, studying or working abroad can broaden horizons and enrich 
knowledge. What's more, overseas visiting experience provides an environment for leaders to study and develop in a cross-cultural way. According to their $\mathrm{CV}$, the international experience of university leaders only three female principals had international backgrounds, accounting for $37.5 \%$.

Table 3. The education background of female presidents

\begin{tabular}{|c|c|c|c|c|}
\hline University & Name & Degree & Study Abroad & Specialty \\
\hline Central South University & $\begin{array}{l}\text { Tian } \\
\text { Hongqi }\end{array}$ & $\begin{array}{c}\text { Doctor of } \\
\text { Engineering }\end{array}$ & & High-speed rail aerodynamics \\
\hline Shandong University & $\begin{array}{c}\text { Fan } \\
\text { Liming }\end{array}$ & $\begin{array}{l}\text { Ph.D. in } \\
\text { Economics }\end{array}$ & $\begin{array}{l}\text { Senior visiting scholar at } \\
\text { Duke University, USA }\end{array}$ & Financial, Tax theory and policy \\
\hline $\begin{array}{c}\text { Central University of Finance } \\
\text { and Economics }\end{array}$ & $\begin{array}{l}\text { Wang } \\
\text { Yaoqi }\end{array}$ & $\begin{array}{l}\text { Ph.D. in } \\
\text { Economics }\end{array}$ & & Investment, project management \\
\hline $\begin{array}{c}\text { Central China Normal } \\
\text { University } \\
\end{array}$ & $\begin{array}{c}\text { Hao } \\
\text { Fanghua } \\
\end{array}$ & $\begin{array}{c}\text { Doctor of } \\
\text { Engineering }\end{array}$ & & $\begin{array}{c}\text { Protection and planning of water } \\
\text { resources }\end{array}$ \\
\hline China University of Petroleum & $\begin{array}{c}\mathrm{Wu} \\
\text { Xiaolin } \\
\end{array}$ & $\begin{array}{c}\text { Doctor of } \\
\text { Engineering }\end{array}$ & & $\begin{array}{l}\text { Fluid-solid two-phase flow } \\
\text { separation technology and theory }\end{array}$ \\
\hline Henan University & Tan Zhen & $\begin{array}{l}\text { Doctor of } \\
\text { education }\end{array}$ & $\begin{array}{c}\text { Senior visiting scholar at } \\
\text { Bangor University, UK }\end{array}$ & Education policy \\
\hline $\begin{array}{l}\text { University of Chinese Academy } \\
\text { of Sciences }\end{array}$ & $\begin{array}{l}\text { Wang } \\
\text { Yanfen }\end{array}$ & $\begin{array}{c}\text { Doctor } \\
\text { (unknown) }\end{array}$ & & Grassland/wetland ecosystem \\
\hline $\begin{array}{c}\text { Nanjing University of Posts and } \\
\text { Telecommunications }\end{array}$ & $\begin{array}{c}\text { Ye } \\
\text { Meilan }\end{array}$ & $\begin{array}{l}\text { Doctor of } \\
\text { History }\end{array}$ & $\begin{array}{l}\text { Training at the University } \\
\text { of California, Berkeley }\end{array}$ & $\begin{array}{l}\text { Management and research of } \\
\text { higher education }\end{array}$ \\
\hline
\end{tabular}

universities, which is conducive to academic contention

\subsection{Characteristics of Employment Experiences}

According to the survey, all the eight female presidents have university working experiences and almost all have been vice presidents for many years, which also reflects the upward position of university presidents at all levels, that is, they are promoted from vice presidents to presidents[11]. For example, Fan Liming, president of Shandong University, served as president of Shanghai University of Finance and Economics for five years. Tan Zhen, president of Henan University, served as dean of Huanghuai College for four and a half years. The other $50 \%$ belongs to the school mobility. Cross-university communication can bring about different management styles and cultures of different and prosperity of universities. Finally, $62.5 \%$ of female presidents held academic part-time jobs in addition to their university positions.(see Table 4 )

\subsection{Characteristics of Job Responsibilities}

In terms of the job responsibilities, among the eight female principals, seven can collect the job division. Among them, six people are responsible for school administration, accounting for $86 \%$. It can be seen that the job responsibilities of female principals are not different because of their gender, and they are generally responsible for school administration as male principals.

Table 4. Employment experiences of female presidents

\begin{tabular}{|c|c|c|c|}
\hline University & Name & College working Experience & Academic part-time job \\
\hline Central South University & $\begin{array}{l}\text { Tian } \\
\text { Hongqi }\end{array}$ & $\begin{array}{l}\text { Vice President of Central South } \\
\text { University }\end{array}$ & \\
\hline Shandong University & $\begin{array}{l}\text { Fan } \\
\text { Liming }\end{array}$ & $\begin{array}{l}\text { 1.Vice President of Shandong } \\
\text { University } \\
\text { 2. President of Shanghai } \\
\text { University of Finance and } \\
\text { Economics }\end{array}$ & $\begin{array}{l}\text { Chairman of the Finance Teaching } \\
\text { Steering Committee of the Ministry of } \\
\text { Education, etc., }\end{array}$ \\
\hline $\begin{array}{l}\text { Central University of } \\
\text { Finance and Economics }\end{array}$ & $\begin{array}{l}\text { Wang } \\
\text { Yaoqi }\end{array}$ & $\begin{array}{l}\text { Vice President of Central } \\
\text { University of Finance and } \\
\text { Economics }\end{array}$ & $\begin{array}{l}\text { Vice President of China Investment } \\
\text { Association, etc., }\end{array}$ \\
\hline $\begin{array}{l}\text { Central China Normal } \\
\text { University }\end{array}$ & $\begin{array}{l}\text { Hao } \\
\text { Fanghua }\end{array}$ & $\begin{array}{l}\text { Vice President of Beijing Normal } \\
\text { University }\end{array}$ & $\begin{array}{l}\text { Deputy Director of the National } \\
\text { Yangtze River Conservation and } \\
\text { Restoration Joint Research Center }\end{array}$ \\
\hline China University of & $\mathrm{Wu}$ & Vice President of China & \\
\hline
\end{tabular}




\begin{tabular}{|c|c|l|c|}
\hline Petroleum & Xiaolin & University of Petroleum & \\
\hline Henan University & Tan Zhen & President of Huanghuai College & \\
\hline $\begin{array}{c}\text { University of Chinese } \\
\text { Academy of Sciences }\end{array}$ & $\begin{array}{c}\text { Wang } \\
\text { Yanfen }\end{array}$ & $\begin{array}{l}\text { Vice President of University of } \\
\text { Chinese Academy of Sciences }\end{array}$ & $\begin{array}{c}\text { Vice President of Chinese Society of } \\
\text { Ecology, etc., }\end{array}$ \\
\hline $\begin{array}{c}\text { Nanjing University of Posts } \\
\text { and Telecommunications }\end{array}$ & $\begin{array}{c}\text { Ye Vice President of Nanjing } \\
\text { Meilan } \\
\text { University of Posts and } \\
\text { Telecommunications } \\
\text { 2. President of Yancheng Institute } \\
\text { of Technology }\end{array}$ & $\begin{array}{c}\text { Member of the Guidance Committee } \\
\text { of History Specialty in Colleges and } \\
\text { Universities Ministry of Education, } \\
\text { etc. }\end{array}$ \\
\hline
\end{tabular}

\section{CONCLUSION}

Generally speaking, the current female principals in china's key universities have many common characteristics, such as political outlook, educational and academic background, academic part-time job and job duties. Therefore, we can make the following summary on the characteristics.

First, the eight female principals all get doctoral degrees with diversified academic backgrounds and have contributed to their respective research fields. However, the proportion of female principals with international background is low.

Second, the source of female principals is limited to higher education institutions, including intra-school mobility and inter-school mobility. Inter-school mobility is conducive to strengthening cooperation and exchanges between universities. Moreover, most female principals are promoted from vice principals to full principals, and the overall promotion tone is upward trend

Third, female principals have rich management experience and have multiple roles. Besides holding positions in colleges and universities, most female principals also have part-time jobs. With their academic achievements and influence, they also hold some important positions in the academic field. These management experiences in different fields can also inject different vitality into university management.

Finally, the total number of female principals in key universities is small and the proportion is low. However, they do not have different job responsibilities because of their gender.

\section{ACKNOWLEDGMENT}

This study is the research result of the general subject of education in 2017 under the 13th five-year plan of the national social science foundation of China (BIA170213): Research on the model of university presidents' competency characteristics and the selection and appointment system from the perspective of professionalism.

\section{REFERENCES}

[1] Geng Youquan, Liu Qiong. Characteristics of the presidents of world-class universities in the US: a study

of the top 20 universities of ARWU issued by Shanghai Jiao Tong University in 2011[J]. Journal of Southeast University (Philosophy and Social Science), 2012, 14(06). (In Chinese)

[2] J.L.Chin. 2003 Division 35 Presidential Address: Feminist Leadership: Feminist Visions and Diverse Voices [J]. Psychology of Women Quarterly, 2004, 28(1).

[3]Guo Aimei. Paradigm Shift in Studies of Gender and Leadership [J]. Journal of Chinese Women's Studies, 2016,(03),117-123. (In Chinese)

[4] Eagly, A.H., Carli, L.L. Through the Labyrinth: The Truth about How Women Become Leaders.[M]. Wang li, Translated. Beijing: Commercial Press, 2011. (In Chinese)

[5] Mary Landon Darden. Women Presidents in American four-year colleges and Universities: An Analysis of Reported Changeable Attributes Contributing to Their Success [D]. Waco: Baylor University, 2006.

[6] Almeda Jacks. Roles, Responsibilities, Celebrations, and Post-presidency Aspirations of Female College Presidents. [D]. Clemson: Clemson University, 2009.

[7] Li Sumin, Luo Weiwei, Niu Menggang. Leadership Qualities of Female Presidents in World-Class Universities in Europe and the US [J]. Modern University Education, 2016 (03). (In Chinese)

[8] Niu Menggang. Sisters at the Helm: A Study of Female Presidents in American Colleges or Universities [D]. Tianjin: Tianjin Normal University, 2018. (In Chinese) 
[9] Wang Yinhan, YU Kai. A Survey of the Female Leaders of Chinese Universities [J]. Fudan Education Forum, 2015, 13(03),21-26. (In Chinese)

[10] Xue Tianxiang. Rational Thinking on the Role of University Presidents [J]. Scientific Chinese, 2005, (05). (In Chinese)
[11] Zhang Yingqiang, Suo Kaifeng. Who are the Presidents in China Universities: From the Survey on the Presidents' Post [J]. Journal of Higher Education, 2016, 37(06). (In Chinese) 